\title{
Standardization of Indonesian Traditional Antihypertensive Medicines (Jamu) through the ACE Inhibitor Mechanism
}

\author{
Aprilita Rina Yanti Eff',*, Sri Teguh Rahayu' ${ }^{1}$, Putu Gita Mahayasih', Muhammad Unggul Januarko²
}

Aprilita Rina Yanti Eff ${ }^{1, *}$, Sri Teguh Rahayu', Putu Gita Mahayasih', Muhammad Unggul Januarko²

'Department of Pharmacy Faculty of Health Science, Universitas Esa unggul, Jakarta, 11510, INDONESIA

${ }^{2}$ Department of Management Faculty

Economics and Bussiness, Universitas Esa Unggul Jakarta, 11510, INDONESIA.

\section{Correspondence}

\section{Aprilita Rina Yanti Eff}

Department of Pharmacy Faculty of Health Science, Universitas Esa Unggul, Jakarta, 11510, INDONESIA.

E-mail: aprilita.rinayanti@esaunggul.ac.id History

- Submission Date: 27-12-2019;

- Review completed: 12-01-2020;

- Accepted Date: 05-02-2020

DOI : 10.5530/pj.2020.12.65

Article Available online

http://www.phcogj.com/v12/i3

\section{Copyright}

(C) 2020 Phcogi.Com. This is an open access article distributed under the terms of the Creative Commons Attribution 4.0 International license.

\section{ABSTRACT}

Introduction: Herbal medicine (jamu) is a traditional Indonesian drug that has been used by the community in efforts to overcome health problems. One of the herbs that are frequently used by the public is antihypertensive jamu. This study aimed to determine the standardization parameters of 8 antihypertensive jamu in the form of specific and nonspecific parameters, antioxidant and angiotensin-converting enzyme inhibitor (ACEI) activity. Materials and methods: Jamu were extracted using ethanol. Nonspecific parameters that are water content, ash content, ash insoluble acid content, level of substances dissolved in alcohol and water, Coliform microbial contamination, and mold/yeast numbers. Determination of specific parameters including determining organoleptic (color and texture), chemical content, identification of infrared spectrum, in-vitro antioxidant activity, and ACE inhibitor activity. Results: nonspecific parameter such is the average water content of $5.92-8.1 \mathrm{v} / \mathrm{w}$; total ash content of 5.85-7.2 w/ w, levels of ash insoluble acid content were $0.45-0.55 \mathrm{w} / \mathrm{w}$ and the level of substances dissolved in alcohol and water were 24.22-54.21 and 24.22-54,21, respectively. The eight extracts were uncontaminated with coliform, mold, and yeast microbes. Antioxidant and ACE inhibitor activity test showed that all eight extracts had antioxidant activity in vitro with $\mathrm{IC}_{50}$ values ranging from $9.31-157.9 \mathrm{ppm}$ and $\mathrm{ACE}$ inhibitor activity with the $\mathrm{IC}_{50}$ value is in the range of 18.37-740.8 ppm. Conclusion: The eight antihypertensive jamu met the standard of extract parameters both the specific and nonspecific and have potential in-vitro activities as ACE inhibitors.

Key words: Herbal medicine (jamu); Antihypertensive; ACE inhibitor; Antioxidant.

\section{INTRODUCTION}

The use of traditional medicines have been widely known from developing countries to developed countries. In some developing countries, traditional medicines are used for health services at the primary level while in developed countries the use of traditional medicines is growing rapidly. The use of traditional medicine in Indonesia has been carried out for centuries but its use is still empirical and its effectiveness and safety have not been supported by scientifically data. ${ }^{1}$

Jamu is one of the Indonesian traditional medicines made from native sources, like roots, bark, flowers, seeds, leaves, and fruits or using ingredients obtained from animals, such as honey, royal jelly, milk and eggs. The use of herbal medicine is still done traditionally, for example in the form of steeping powder or liquid containing all ingredients of plants that make up herbs. ${ }^{2}$ Herbal medicine is an option for some people to maintain health because the price is inexpensive, there are no side effects on the body and the raw materials are easy to find.

Prevalence of hypertension in Indonesia based on the results of measurements blood pressure by $25.8 \%$. Most of the cases of hypertension in the community $(63,2 \%)$ undiagnosed. Basic Health Research Data (Riskesdas) in 2013 showed that $30.4 \%$ of households in Indonesia utilize health services traditional, including $49 \%$ of houses stairs use traditional medicinal herbs. Meanwhile, Riskesdas in 2010 showed $60 \%$ of the population Indonesia was over the age of 15 years stated he once drank jamu, and $90 \%$ of them indicated their existence the benefits of drinking jamu.

Using traditional drug as part of the treatment of hypertension increasingly increased in the last decade. This matter caused by several factors, especially the prices of traditional medicines considered cheaper with less side effect. ${ }^{4}$ The goal of treatment of hypertension with medicinal plants is to treat high blood pressure by correcting the cause according to the philosophy of medicinal plants as constructive medicine, namely repairing/building damaged organs or systems that cause hypertension. Medicinal plants have advantages in the treatment of hypertension because generally, medicinal plants have a function other than managing hypertension as well as treating comorbidities or complications as a result of high blood pressure. ${ }^{5}$

One of the drugs used to restore blood pressure in patients with hypertension obtains an Angiotensin Converting Enzymes (ACE) inhibitor. ACE inhibitors are the drugs of choice because, in addition to treating hypertension, they are equally beneficial for cardiovascular diseases, namely congestive heart failure and left ventricular dysfunction, enhancing the function and anatomy of arteries, improving endothelial function, regressing and stabilizing atherosclerotic plaques and in diabetic nephropathy.

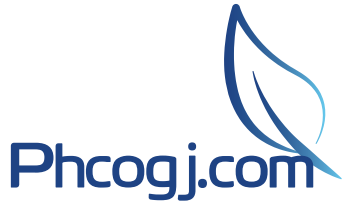

Cite this article: Yanti Eff AR, Rahayu ST, Mahayasih PG, Januarko MU. Standardization of Indonesian Traditional Antihypertensive Medicines (Jamu) through the ACE Inhibitor Mechanism. Pharmacog J. 2020;12(3):422-9. 
Medicines included in ACE inhibitors work by inhibiting the effects of angiotensin II as a vasoconstrictor. The role of ACE inhibitors in hypertension in addition to reducing levels of angiotensin II also increases levels of bradykinin, which contributes as a vasodilator. Vasodilation decreases peripheral vessel resistance, preload, and afterload in the heart, thereby reducing blood pressure. ${ }^{6}$

Some medicinal plants are identified to produce antihypertensive effects and work by inhibiting ACE. ACE inhibitors derived from nature have safety and economic value. ACE inhibitors derived from natural product generally comes from groups of compound peptides, proanthocyanidin, terpenoids and tannins. ${ }^{7,8}$

The standardization of antihypertensive herbs (jamu) needs to be done to anticipate global competition in the field of jamu and the availability of antihypertensive jamu that are safe, efficient, and scientifically tested. Saintification of jamu will provide a scientific foundation for the use of herbal medicine empirically through research based on health services and community welfare. ${ }^{9}$

This study aims to standardization and saintification antihypertensive jamu through inhibition of the Angiotensin-Converting Enzyme to anticipate global competition in the field of herbal medicine and the availability of safe, effective and scientifically tested antihypertensive herbs.

\section{MATERIAL AND METHODS}

\section{Materials}

The test material consisted of 8 antihypertensive herbal brands (Jamu) purchased from drugstores in Jakarta, ethanol (Bratachem), Aquadest (Bratachem), Aquademineral (Bratachem), Ethyl Acetate (Merck), DMSO (Merck), Hipurat Acid (Sigma), Captopril (Sigma), HHL (Sigma), ACE from rabbit lung (Sigma), $\mathrm{NaOH}$ (Merck), Boric Acid (Sigma).

\section{Methods}

\section{Extraction and identification of the specific and non-specific parameters}

The eight (8) antihypertensive herbs (jamu) were extracted with ethanol by maceration then concentrated until a thick extract was obtained. Determination of non-specific parameters includes the examination of ash content, acid insoluble ash content, water content, water-soluble extract content, ethanol-soluble compound, and microbial contamination using the ALT method. Determination of specific parameters includes organoleptic, extract chemical content and identification of infrared spectrum.

\section{In-vitro antioxidant activity assay}

Antioxidant activity assay was carried out in a test tube by measuring the absorbance DPPH (H (2,2-diphenyl-1picrylhyrazyl) reagent solution and the extract solution. A total of $1.5 \mathrm{ml}$ extract was added 3 $\mathrm{ml} \mathrm{DPPH}$ and mixed until homogeneous. This mixture was incubated for 30 minutes, and then the absorption was measured at a wavelength $516 \mathrm{~nm}$. Methanol is used as a blank and Vitamin C as reference drug. Free radical scavenging activity the extract is determined by calculating $\mathrm{IC}_{50}$ value, which represents the effective concentration required to reduce $50 \%$ uptake intensity compared to the reagent solution. $\mathrm{IC}_{50}$ was calculated of a percent (\%) of various absorbance reductions extract concentration using linear regression.

\section{Preliminary test of inhibition of angiotensin-converting enzyme} activity

Preliminary Test Inhibition of Angiotensin-Conversion Enzyme Activity included optimum determination of wavelength, temperature, incubation time, and substrate concentration. Determination of the maximum wavelength is carried out by using hypuric acid at a wavelength of $200-400 \mathrm{~nm}$. The optimum incubation time test was taken out for $15,30,60,90$, and 120 minutes. The optimum temperature was determined by incubating the test solution at temperatures of 30, 32, 35,37 , and $40^{\circ} \mathrm{C}$. Determination of optimum substrate concentration was performed using Hyppuryl-Histidyl-Leucine (HHL) substrate at concentration of $2,4,5,6,8$, and ten $\mathrm{mM}$.

\section{ACE inhibitory activity assay measurement}

The extracts of the antihypertensive jamu were accurately measured to inhibit the specific activity of Angiotensin-Converting Enzyme (ACE). The examination was conducted out using a spectrophotometer under aerobic conditions. The excellent results of the optimization procedure was applied to measure the ACE activity against the extract objectively accurately.

Test solution of $50 \mu \mathrm{L}$ was gently put into a test tube, then $50 \mu \mathrm{L}$ of HHL substrate solution was added thoughtfully to the optimum concentration. In addition, pre-incubation of the test solution was carried out at $37^{\circ} \mathrm{C}$ for 10 minutes. After pre-incubation, $100 \mu \mathrm{L}$ of the ACE solution is added to the test tube and homogenized using a vortex mixer. The prepared mixture was incubated at optimal temperature and optimum time. Then immediately added $250 \mu \mathrm{L} \mathrm{HCI} 1 \mathrm{~N}$ to discontinue the reaction. The formed hippuric acid was carefully extracted using 1.5 $\mathrm{mL}$ ethyl acetate. The prepared mixture was centrifuged for 10 minutes, and an ethyl acetate layer was gently taken at the top and evaporated at $100^{\circ} \mathrm{C}$ for 5 minutes. The formed precipitate was dissolved with 3 $\mathrm{mL}$ distilled water, and the absorption was precisely measured using a spectrophotometer at a maximum wavelength. Analyses with the similar procedure was carried out on Captopril as a reference drug. Boric acid buffer solution as blanks and control blanks. ACE enzyme solution was added to the blank solution mixture, while the control blanks do not include enzymes. ${ }^{10,11}$

Percent inhibition is calculated using the formula A / B x 100\%, where $\mathrm{A}=$ [absorbance of the blank solution] -absorbance control blank - absorbance of the sample solution; B = [Absorbance of the blank solution - absorbance of the blank control solution] - absorbance of control sample. ${ }^{12}$

\section{RESULTS}

The composition of plants used in antihypertensive jamu can be seen in Table 1.

The results of measuring non-specific and specific parameters of each extract can be seen in Tables 2 and 3, in-vitro measuring antioxidant activity $\left(\mathrm{IC}_{50}\right)$ and ACE inhibitor activity $\left(\mathrm{IC}_{50}\right)$ can be seen in Table 4 and 5 .

Results of preliminary test of inhibition of Angiotensin-Converting Enzyme activity show that the maximum absorption of hippuric acid is at a wavelength of $246 \mathrm{~nm}$. The optimum incubation time remains 90 minutes. The optimum incubation temperature is shown at $37^{\circ} \mathrm{C}$, and the optimum substrate concentration is present at eight $\mathrm{mM}$.

\section{DISCUSSION}

The utilization of traditional medicines aimed at maintaining health and treating diseases in developing countries is grow rapidly. Indonesia has many medicinal plants that are potentially to be used as traditional prescriptions and have been used for generations. Traditional medicine in Indonesia is known as jamu. ${ }^{1}$ Some medicinal plants in Indonesia possess antihypertensive properties. National survey results show that $46.4 \%$ of Indonesian people suffer from hypertension, but only about 9\% receive adequate treatment. Patients with chronic hypertension 
Table 1: Composition of plants in antihypertensive jamu.

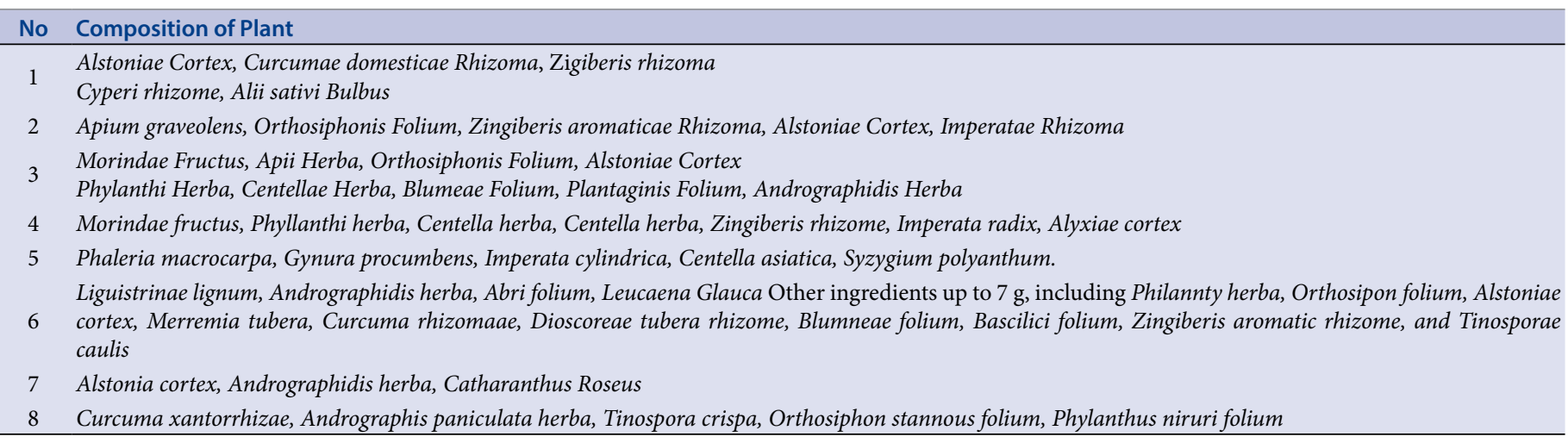

\section{Table 2: The non-specific parameters each extract of jamu.}

\begin{tabular}{|c|c|c|c|c|c|c|c|}
\hline $\begin{array}{l}\text { No of } \\
\text { extracts }\end{array}$ & $\begin{array}{l}\text { water content } \\
\qquad(\mathrm{v} / \mathrm{w})\end{array}$ & $\begin{array}{l}\text { ash content } \\
\qquad(w / w)\end{array}$ & $\begin{array}{c}\text { Ash insoluble acid } \\
\text { content }\end{array}$ & $\begin{array}{l}\text { level of substances } \\
\text { dissolved in } \\
\text { alcohol }(\%)\end{array}$ & $\begin{array}{c}\text { Level of substances } \\
\text { dissolved water } \\
\text { (\%) }\end{array}$ & $\begin{array}{c}\text { Coliform microbial } \\
\text { contamination } \\
(\text { colony } / g)\end{array}$ & $\begin{array}{l}\text { mold/yeast } \\
\text { numbers } \\
\text { (colony/g) }\end{array}$ \\
\hline 1 & $5.67 \pm 0.45$ & $6.42 \pm 0.06$ & $0.15 \pm 0.02$ & $45.72 \pm 2.5$ & $24.29 \pm 2.99$ & negative & negative \\
\hline 2 & $6.04 \pm 0.24$ & $6.04 \pm 0.06$ & $0.06 \pm 0.01$ & $58.37 \pm 1.89$ & $35.5 \pm 3.83$ & negative & negative \\
\hline 3 & $8.1 \pm 0.93$ & $7.24 \pm 0.36$ & $0.45 \pm 0.09$ & $61.1 \pm 3.34$ & $25.28 \pm 1.38$ & negative & negative \\
\hline 4 & $6.82 \pm 0.2$ & $4.63 \pm 0.08$ & $0.28 \pm 0.02$ & $57.62 \pm 0.55$ & $28.38 \pm 0.68$ & negative & negative \\
\hline 5 & $7.68 \pm 0.03$ & $4.8 \pm 0.24$ & $0.61 \pm 0.95$ & $49.2 \pm 0.8$ & $32.76 \pm 0.9$ & negative & negative \\
\hline 6 & $7.29 \pm 0.58$ & $4.70 \pm 0.43$ & $0.27 \pm 0.02$ & $48.2 \pm 1.17$ & $43.1 \pm 0.36$ & negative & negative \\
\hline 7 & $6.74 \pm 0.35$ & $6.24 \pm 0.52$ & $0.09 \pm 0.07$ & $53.33 \pm 1.93$ & $29.19 \pm 1.06$ & negative & negative \\
\hline 8 & $5.85 \pm 0.24$ & $5.92 \pm 0.18$ & $0.41 \pm 0.07$ & $60,16 \pm 1.33$ & $31.93 \pm 1.72$ & negative & negative \\
\hline
\end{tabular}

Table 3: The specific parameters each extract of jamu.

\begin{tabular}{|c|c|c|c|}
\hline No of extracts & $\begin{array}{c}\text { Organoleptic } \\
\text { (colour and texture) }\end{array}$ & Chemical content & identification of infrared spectrum \\
\hline 1 & yellowish-brown and paste & Flavonoid, alkaloid, tannin, saponin, triterpenoid & $\mathrm{C}-\mathrm{O} ; \mathrm{N}=\mathrm{O} ; \mathrm{N}=\mathrm{H} ; \mathrm{C}=\mathrm{O}, \mathrm{C}-\mathrm{H}$ (aliphatic); - $\mathrm{OH}$ \\
\hline 2 & yellowish-brown and liquid & Flavonoid, alkaloid, tannin, saponin, triterpenoid & $\mathrm{C}-\mathrm{O} ; \mathrm{N}=\mathrm{O} ; \mathrm{C}-\mathrm{H}$ (aromatic); N-H; -OH \\
\hline 3 & yellowish-brown and paste & $\begin{array}{c}\text { Flavonoid, alkaloid, tannin, saponin, steroid, } \\
\text { triterpenoid }\end{array}$ & $\mathrm{C}=\mathrm{O} ; \mathrm{N}-\mathrm{H}$ \\
\hline 4 & yellowish-brown and paste & Flavonoid, tannin, saponin, steroid & $\begin{array}{c}\mathrm{C}=\mathrm{O} ;-\mathrm{OH} ; \mathrm{C}=\mathrm{C} ; \mathrm{C}-\mathrm{O}^{\prime} \mathrm{C}-\mathrm{H} \text { (aromatic) } ; \mathrm{C}-\mathrm{H} \\
\text { (aliphatic) }\end{array}$ \\
\hline 5 & yellowish-brown and paste & $\begin{array}{c}\text { Flavonoid, alkaloid, tannin, saponin, steroid, } \\
\text { triterpenoid }\end{array}$ & C-H (aliphatic); -OH; C=C; C-N; C-O \\
\hline 6 & yellowish-brown and paste & Flavonoid, alkaloid, tannin, saponin, steroid & -OH; C-H (aliphatic); C-O; alkuna \\
\hline 7 & yellowish-brown and paste & $\begin{array}{c}\text { Flavonoid, alkaloid, tannin, saponin, quinon, } \\
\text { triterpenoid }\end{array}$ & $-\mathrm{OH} ; \mathrm{C}-\mathrm{H}$ (aliphatic); $\mathrm{C}=\mathrm{O} ; \mathrm{C}=\mathrm{C}$ (aromatic); $\mathrm{C}-\mathrm{N}$ \\
\hline 8 & yellowish-brown and liquid & $\begin{array}{c}\text { Flavonoid, alkaloid, tannin, saponin, steroid, } \\
\text { triterpenoid }\end{array}$ & $\begin{array}{l}\mathrm{OH} ; \mathrm{C}-\mathrm{H} \text { (aliphatic); } \mathrm{C}=\mathrm{C} ; \mathrm{C}=\mathrm{O} ; \mathrm{C}-\mathrm{N} ; \mathrm{C}-\mathrm{H} \\
\text { (aromatic); }\end{array}$ \\
\hline
\end{tabular}

Table 4: In-vitro antioxidant activity $\left({ } C_{50}\right)$.

\begin{tabular}{cc}
\hline No of extracts & $\mathrm{IC}_{50}(\mathrm{ppm})$ \\
\hline 1 & 9.36 \\
2 & 79.8 \\
3 & 78.68 \\
4 & 24.43 \\
5 & 11.4 \\
6 & 67.85 \\
7 & 157.9 \\
8 & 11.4 \\
\hline
\end{tabular}

Table 5: ACE inhibitor activity $\left(\mathrm{IC}_{50}\right)$.

\begin{tabular}{cc}
\hline No of extracts & $\mathrm{IC}_{50}(\mathrm{ppm})$ \\
\hline 1 & 740,8 \\
2 & 319.5 \\
3 & 455.98 \\
4 & 292.15 \\
5 & 18.37 \\
6 & 475.97 \\
7 & 265.3 \\
8 & 103.75 \\
\hline
\end{tabular}


tend to control their blood pressure through various methods, one of which is by using antihypertensive herbs. ${ }^{1,3,13}$

Therefore, that traditional medicines can be used in health care facilities, and the availability of safe and nutritious herbal medicine needs to be standardized. Standardization of herbal medicine refers to regulations of Indonesia Minister of Health No. 1109 / Menkes / Per / IX / 2007 regarding the administration of effective treatment alternative, complementary health facilities. Standardization represent a critical stage in conducting research and drug development natural medicine in Indonesia to guarantee quality and safety of these drug preparations. In this research, standardization of antihypertensive jamu extract carried out which involves non-specific parameter, example water content, ash content, and acid insoluble ash content, and specific parameters particularly organoleptic, chemical content, and IR chromatogram pattern. ${ }^{14}$ Based on the results presented in Table 2, the water content of the herbal extract obtains $5.67-7.92 \% \mathrm{v} / \mathrm{w}$ or less than $10 \%$, so that concluded the eight extracts fulfilled standard specifications. The water content in the extract is barely than $10 \%$ minimize the growth of fungi and mold so that the durability and quality of the extract when storage remains good. Ash content measurement is intended to determine the quantity of inorganic material or minerals left after the graying process. The eight herbal extracts have a total ash content of 2.46-7.24\%. This value complies with the standard requirements for total ash content, which is equal to no more than $10.2 \%$. The physical properties of an ingredient or extract can be influenced by the levels of inorganic or mineral compounds contained in the extract.

Determination of acid-insoluble ash content aims to determine the amount of ash content obtained from external factors or contamination originating from sand or soil. The Indonesian Ministry of Health requires that the acid insoluble ash level should not be more than $0.7 \%$. The measurement results show that the eight herbal extracts meet the acid insoluble ash content standard. Determination of acidinsoluble ash content is proposed to assess extracts from earth and sand contamination. Determination of the concentration of extract in the solvent water and ethanol is an indicator of the number levels of compounds that can be found. The physical properties of plants determine the amount of compound content that can be dissolved in solutions. The results showed that the herbal extract has the highest solubility in water, which is $45.25-60.12 \%$. The eighth extracts show more soluble in alcohol solvents, so when formulating the product of the extract can using alcohol solvents. ${ }^{15}$

Testing for bacterial contamination is one of the tests to measure the purity of the extract. This test comprises the determination of the number of microorganisms allowed and to indicate the absence of certain bacteria in the extract. The test results showed that the eight extracts were uncontaminated with coliform, mold, and yeast microbes. The maximum limit of microbial contamination in herbal medicines is present $1 \times 10^{5}$ colonies / $\mathrm{g}$ while the maximum limit of yeast mold contamination is $1 \times 10^{-3}$ colonies/g. ${ }^{15}$

Organoleptic was done by observing the physical form of the extract aim as an initial introduction to use the senses. Determination was done by describing the shape and color. Extracts 1, 3, 4, 5, 6, and 7 are yellowish-brown in color and the form of a paste. While extracts 2 and 8 yellowish-brown and liquid. Phytochemical screening aims to find out the existence of groups of secondary metabolites contained in the extract and can also be describe extract content qualitatively. Phytochemical screening results showed that the extract contained flavonoids, alkaloids, tannins, saponins, quinones and triterpenoids. Infrared Spectrophotometry is a method that can observe the interaction of molecules with electromagnetic radiation that is in the wavelength region of $0.75-1000 \mu \mathrm{m}$ or at wavenumbers $13,000-10$
$\mathrm{cm}^{-1}$.This method can provide useful information for qualitative and quantitative analysis, as well as assist in the application of the formula for building a compound. ${ }^{16}$

Antioxidant activity test results showed that all eight extracts had antioxidant activity in vitro with $\mathrm{IC}_{50}$ values ranging from $9.31-157.9$ $\mathrm{ppm}$. As a comparison, vitamin $\mathrm{C}$ was used with an $\mathrm{IC}_{50}$ value of 5.32 $\mathrm{ppm}$. Jung et al. divided the intensity of the level of antioxidant strength in 5 categories, very active, if the $\mathrm{IC}_{50}$ value $<50 \mathrm{ppm}$; active if the $\mathrm{IC}_{50}$ is $50-100 \mathrm{ppm}$; while if the $\mathrm{IC}_{50}$ value is $101-250 \mathrm{ppm}$; weak if the $\mathrm{IC}_{50}$ value is $250-500 \mathrm{ppm}$ and not active if the $\mathrm{IC}_{50}$ value is $>500 \mathrm{ppm}$. From Table 4 it can be seen that herbal extracts number 1, 4, 7 and eight are classified as very active antioxidants, extracts numbers 2,3 and five are classified as active antioxidants, and extract number 6 is classified as moderate antioxidants. ${ }^{17}$

DPPH is an oxidizing agent that can be a free radical in testing antioxidant activity assay. Using this method is easy, simple, sensitive, fast, and requires a small sample. The test was done by calculating the value of $\mathrm{IC}_{50}$, namely the concentration of the test extract that can capture $50 \%$ of free radicals obtained through the regression equation. The smaller the $\mathrm{IC}_{50}$ value of a test compound, the more effective it is as a free radical antidote. The ability to reduce DPPH radicals in herbal extracts is related to compounds contained in it, namely compounds polyphenols and tannins. Polyphenol compounds and tannins can donate hydrogen. Antioxidant activity of these compounds occurs in the cessation of radical chain reactions that occur. Compounds that have antioxidant activity will react with DPPH through electron administration from antioxidant compounds to DPPH. This reaction causes a decrease in the color intensity of the solution Purple DPPH. The greater the concentration then the intensity of the purple color decreases DPPH that can be measured using absorption UV-VIS spectrophotometer at a wavelength $516 \mathrm{~nm} \cdot{ }^{16,18}$

The preliminary test of ACE inhibitory activity aims to determine the optimum conditions for enzyme activity so that it can take place optimally on the following sample measurements. Optimization was done because the rate of the reaction catalyzed by enzymes is influenced by several factors, including temperature, $\mathrm{pH}$, and substrate concentration. ${ }^{19}$ In the preliminary test, the maximum wavelength is determined using hippuric acid, incubation time, incubation temperature, and substrate concentration to be used at the time of testing. In the preliminary investigation, $\mathrm{pH}$ optimization was not carried out because based on the optimal $\mathrm{pH}$ incubation literature in the test was $8.3 .^{20}$ The higher the absorption is obtained, the more products are produced, so the enzyme activity becomes greater. Based on the preliminary test results of ACE inhibitory activity, optimum conditions were acquired at 246 $\mathrm{nm}$ wavelength, the optimum incubation time of 90 minutes, substrate concentration of $8 \mathrm{mM}$, and incubation temperature of $37^{\circ} \mathrm{C}$.

ACE inhibitory activity assay was performed on captopril (as reference drug) and herbal extract sample no. 1-8. The results showed that the $\mathrm{IC}_{50}$ value is in the range of 265.3-740.8 ppm. Synthetic ACE inhibitors such as Captopril, Ramipril, and Lisinopril have side effects such as dry cough, hyperkalemia, rash, dizziness, and changes in taste. Therefore, it is developed ACE inhibitors derived from natural materials both from food or plants. ACE inhibitors from natural ingredients are considered safer than synthetic replace ACE inhibitor. ${ }^{8}$ Secondary metabolites produced by plants are natural compounds that are identified as ACE inhibitors, namely flavonoids, hydrolyzed tannins, xanthones, procyanidin, and caffeoylquinic acid. Several studies have shown that many ACE inhibitors come from plants, but the identification of active compounds is still minimal. In Indonesia, various plants have been used to treat hypertension. Some Indonesian medicinal plants that have antihypertensive activity, namely Persea americana Mill, Phalleria macrocarpa (Scheff) Boerl], Oxalis corniculata Linn, Catharanthus 
roseus (L.) G. Donn), Dendropthoe pentandra (L. Miq), Swietenia mahogany L (Jack).), Gynura procumbens (Lorr) Merr), Melia azedarach L, Hibiscus rosa-sinensis L, Alstoniae Cortex, Curcumae xanthorrhizae, Zingiberis aromatic, Cyperi rotunda, Alii sativi, Morinda citrofolia, Centella asiatica, Orthosiphonis aristatus, Stachytapheta mutabilis and Blumea balsamifera. ${ }^{5,21}$

Clinical study the efficacy of boiled of Hypertension Herbs Compared to steeped hypertension carried out by Triyono et al. consists of celery herbs, Centella herbs, Orthoshipon leaves, Ginger rhizomes, Turmeric rhizomes, and Phyllanthus herbs. Steeping herbal remedy exerts the effect of reducing blood pressure (systolic and diastolic) and increasing the SF-36 quality of life score equivalent to boiled Herbs. Stepping herbal medicine and herbal decoction exerts the effect of reducing blood pressure to normal (normotensive), each of $63 \%$ and $56 \%$ of the research subjects. Steeping herbal medicine can eliminate clinical symptoms of hypertension (dizziness/headache stiff neck/whiny and rheumatic pain) the subject of the study is moderately faster than the herbal decoction. ${ }^{22}$

Some classes of antihypertensive drugs that are often used as monotherapy treatment are diuretics, beta-blockers, Angiotensinconverting enzyme inhibitors (ACEI), Angiotensin receptor blocker (ARB), and Calcium channel blockers (CCB). The use of combination therapy is given if treatment with monotherapies has not been able to control blood pressure correctly. Antihypertensive drug combinations that are frequently used comprise a combination of diuretics, $\beta$-blockers, and ACE-inhibitors. Hypertension herbal medicine is also a combination of several dried powder medicinal plants that have different mechanisms of action. The combination of several medicinal plants is expected to have a synergistic effect from the chemical content of some medicinal plants in lowering blood pressure. ${ }^{23}$ Jamu extract number 5 possesses the slightest $\mathrm{IC}_{50}$ value of $18.37 \mathrm{ppm}$. This herbal extract consists precisely of several medicinal plants, namely: Phaleria macrocarpa, Gynura procumbens, Imperata cylindrica, Centella asiatica, and Syzygium polyanthum.

Phaleria macrocarpa is one of Indonesia's native plants which owns medicinal properties. Empirical leaves and fruits have been used to treat various types of illnesses like cancer, liver, heart disease, diabetes, rheumatism, kidney disorders, strokes, and high blood pressure. ${ }^{24}$ Mahkota Dewa contains mahkotaside, mangiferin, kaempferol-3-O-d glucoside, dodecanoic acid, palmitic acid, ethyl stearic, and sucrose. ${ }^{25}$ Mahkota Dewa additionally exerts an antidiabetic effect which works to inhibit alfa glucosidase and has an antidiabetic effect in rats induced by streptozotocin. ${ }^{26,27}$ The results of a study conducted by Eff et al. showed that the extracts of leaves and fruits have activity as ACE inhibitors with $\mathrm{IC}_{50}$ values on leaves is $189.13 \mathrm{ppm}$ in petroleum ether, $157.74 \mathrm{ppm}$ in ethyl acetate and $101.52 \mathrm{ppm}$ in methanol while the $\mathrm{IC}_{50}$ values in fruit were $161.7 \mathrm{ppm}$ in petroleum ether, $139.11 \mathrm{ppm}$ in ethyl acetate and $122.38 \mathrm{ppm}$ in methanol. ${ }^{28}$

Gynura procumbens is used for the treatment of various diseases like hypertension, vasodilators, fever, diabetes mellitus, and hyperlipidemia in Indonesia. ${ }^{29} \mathrm{G}$ procumbens water extract in rats has anti-hypertensive effects, decreases lactate dehydrogenase levels, creatinine phosphate kinase, and increases nitric oxide. Ethanol extract of $G$ procumbens can reduce triglyceride and serum cholesterol levels in sterptozotosininduced diabetic rats. The antidiabetic effect of $G$ procumbens ethanol extract is comparable to Biguanid. G procumbens increases glucose metabolism via the glycolysis pathway and inhibits endogenous liver glucose production through the gluconeogenesis pathway. ${ }^{30}$ Extracts of G procumbens has activity as an ACE inhibitor with an IC50 value of $431.54 \mathrm{ppm}$ in petroleum ether, $227.41 \mathrm{ppm}$ in ethyl acetate and 452.69 in methanol.
Imperata cylindrica roots contain twelve phenolic compounds were isolated, such as flavonoids, simple phenols, phenolic acids, coumarins, and lignans, potassium, cylindrene, and graminone B. ${ }^{31}$ Flavonoids possess the effect of inhibiting Angiotensin Converting Enzym. Inhibition of angiotensin production causes a reduction in aldosterone secretion resulting in natriuresis, a decrease in intravascular fluid volume, and a decrease in blood pressure. ${ }^{32}$ Potassium obtains an antirenin an enzyme that plays a role in the production of angiotensin. Potassium is additionally an aldosterone inhibitor. Potassium can decrease membrane potential, causing relaxation of vascular smooth muscle. Relaxation of smooth muscle causes the diameter of blood vessels to widen so that blood pressure drops. Cylindrene produces inhibitory activity against the contraction of vascular smooth muscle and Graminone B is a vasodilator agent. ${ }^{29}$ The results of a study conducted by Delima and Sari, 2018 showed that the roots of I cylindrica affected lowering blood pressure in healthy subjects. The mean systolic and diastolic blood pressure in subjects who were given boiled I cylindrica roots were significantly lower than blood pressure before being given an infusion $(\mathrm{p}<0.01)$. The decoction of the weed root decreases both systolic and diastolic blood pressure in the subject. Mean systole blood pressure after taking I cylindrica roots infusion $(95.33 \pm 5.381) \mathrm{mmHg}$, lower than before drinking infusion of (107.07 $\pm 5.800) \mathrm{mmHg}$. The mean diastolic pressure after drinking Imperata root infusion was $(64.27 \pm 3.693) \mathrm{mmHg}$, lower than before drinking Imperata root infusion of $(70.00 \pm 3.854) \mathrm{mmHg}^{33}$

Centella asiatica is an herbal plant of the Mackinlayaceae family. C. asiatica can be found in countries like Indonesia, Sri Lanka, Malaysia, Australia, Iran, Melanesia, New Guinea, and other Asian countries. C. asiatica has chemical content, namely triterpenoids, essential oils, flavonoids, and other components. Triterpenoids are the main component of $C$. asiatica and become a marker of the quality of $C$. asiatica. Triterpenes are in the form of asiatic acid, madecassic acid, and their respective glycosides, asiaticoside, and madecassoside. Essential oils such as caryophyllene, farnesol, humulene, and bicyclogerma. Flavonoids in the kind of quercetin, routine catechin, and naringin and other components in the form of polysaccharides, polyene, alkene, fatty acids, sesquiterpenes, alkaloids, sterols, carotenoids, and tannins. ${ }^{34}$ Asiatic acid is a triterpenoid that has antioxidant, anti-inflammatory, antihyperlipidemic, and antidiabetic activity in mice induced by Streptozotocin. A study conducted by Manesa et al. 2016 showed that Asiatic acid exerts an antihypertensive effect, improving vascular function through the retention of endothelial nitric oxide synthase (eNOS) and p47phox expression in rats of L-NAME hypertension. Asiatic acid also has ACE inhibitor action by reducing the activity of the angiotensin renin system and increasing vascular function by decreasing sympathetic nerve activity. ${ }^{35}$

Bay leaves (Syzygium polyanthum) possesses a variety of pharmacological activities, namely as antihypertensive, antidiabetic, antioxidant, antidiarrheal, anti-inflammatory, immunomodulatory, antibacterial, and anticancer. Active compounds which play a role in its pharmacological activities are quercetin, gallic acid, caffeic acid, and phenolic acid. ${ }^{36,37}$ Water and methanol extract of $S$. polyanthum possess antihypertensive activity in mice, caused by terpenoid phenolic (eugenol), tannins, and flavonoids compounds. Eugenol has vasorelaxant so that it can reduce blood pressure. ${ }^{38}$ Antihypertensive effects are thought to inhibit beta-adrenergic and cholinergic receptors through nitrite oxides production. ${ }^{39} S$. polyanthum leaves have ACE inhibitor activity at a concentration of $100 \mathrm{ppm}$, with the percentage of inhibition is $53.37 \%{ }^{40} \mathrm{~S}$. polyanthum leaves extract causes vasorelaxation and inhibits Angiotensin-Converting Enzyme (ACE), thereby reducing elevated blood pressure. Studies conducted by Ismail and Wan Ahmad show that water and methanol extracts of $S$. polyanthum cause vasorelaxation in WKY and SHR mice. ${ }^{39}$ 


\section{CONCLUSION}

The eight antihypertensive jamu met the standard of extract parameters both the specific and non-specific and have potential activities as ACE inhibitors.

\section{ACKNOWLEDGEMENT}

The authors express their gratitude to the Indonesia Ministry of Research, Technology and Higher Education for the funding this research.

\section{REFERENCES}

1. Herman MJ, Supardi S, Handayani RS. Policy on herbal traditional medicines therapy in three provinces in indonesia. Bul Penelit Kesehat. 2013;41(2):111-9.

2. Riswan S, Roemantio SH. Jamu as traditional medicine, in java Indonesia South Paciflc Study. 2002;23(1):1-10.

3. Indonesia M of H. Basic health research 2013. Heal Res Dev Agency, Indonesia Minist Heal. 2013;72-7.

4. Hussaana A, Sarosa $H$, Indrayani UD. Formula jamu antihipertensi and captopril are equally effective in patients with hypertension. Universa Med. 2016;35(2):81-8.

5. Iskandar Y. Medicinal plants that are efficacious as antihypertensive. Sci Pap. 2007;1-27.

6. Tardif J. Angiotensin-converting enzyme inhibitors and atherosclerotic plaque : a key role in the cardiovascular protection of patients with coronary artery disease. Eur Heart J. 2009;11 supplementary:E9-16.

7. Balasuriya BWN, Rupasinghe HPV. Plant flavonoids as angiotensin converting enzyme inhibitors in regulation of hypertension. Funct Foods Heal Dis. $2011 ; 5: 172-88$

8. Lettre DP, Kumar R, Kumar A, Sharma R, Baruwa A. Pharmacological review on natural ACE inhibitors. Der Pharm Lett. 2010;2(2):273-93.

9. Indonesia $\mathrm{M}$ of $\mathrm{H}$. Regulation of the Minister of Health of Republic of Indonesia No: 003/MENKES/PER/I/ 2010 about Saintification of jamu based on research health services. 2010;pp:1-15.

10. Gao D, Chang T, Li H, Cao Y. Angiotensin I-converting enzyme inhibitor derived from cottonseed protein hydrolysate. African J Biotechnol. 2010;9(53):8977-82.

11. Meyer J, Bütikofer U, Walther B, Wechsler D, Sieber R. Hot topic: Changes in angiotensin-converting enzyme inhibition and concentrations of the tripeptides Val-Pro-Pro and Ile-Pro-Pro during ripening of different Swiss cheese varieties. J Dairy Sci. 2009;92(3):826-36.

12. Sp L, Hadira O. In vitro inhibitory potential of selected malaysian plants against key enzymes involved in hyperglycemia. Mal J Nutr. 2011;17(1):77-86.

13. Abascal EY, Abascal K. Treating hypertension botanically. Altern Complement Ther. 2001;October:284-90.

14. Hidayati DN, Cicih Sumiarsih UM. Non-specific standardization of leaves and caulis (Crescentia cujete Linn). J IIm Cendekia Eksakta. 2005;19-23.

15. Departemen Kesehatan RI. General standard parameters of medicinal plant extracts. 2000. p. 13-30.

16. White JL. Interpretation of infrared spectra of soil minerals. Soil Sci. 2000;112(1):22-31.

17. Jun M, Fu HY, Hong J, Wan X, Yang CS, Ho CT. Comparison of antioxidant activities of isoflavones from kudzu root (Pueraria lobata Ohwi). J Food Sci. 2003;68(6):2117-22

18. Garcia E, Oldoni T, Severino MA, Lugoercia A, Grande R. Antioxidant activity by DPPH assay of potential solutions to be applied on bleached Teeth. Braz Dent J. 2012;23(1):22-7.

19. Murray RK, Granner D, Rodwell V. Biokimia harper translated from harper's illustrated biochemistry 27th ed oleh Brahm U dan Nanda Wulandari. 2006.
20. Cushman DW, Cheung HS. Spectrophotometric assay and properties of the angiotensin-converting enzyme of rabbit lung. Biochem Pharmacol. $1971 ; 20(7): 1637-48$

21. Indonesia pharmacists association. Daftar obat alam indonesia (DOA). III. 2008 p.55-57.

22. Triyono A, Ridha P, Ardianto D. Clinical trial the efficacy of boiled hypertension herbs compared with steeped hypertension herbs. J Ilmu Kefarmasian Indonesia. 2018;16(1):78-85.

23. Rumiyati, Arif $\mathrm{RH}$, Arini DM, Dea NS. Antihypertensive testing of combination of Apium graveolans L., Orthosiphon stamineus Benth., and Morinda citrifoliaL extract on normotensive and hypertensive Sprague dawley Rats. Maj Obat Tradis. 2016;21(3):149-56.

24. Harmanto. Potential of the Mahkota Dewa as traditional medicine. In: One day seminar. Research and development center for pharmacy and traditional medicine of the Republic of Indonesia, Jakarta;2003.

25. Oshimi S, Zaima K, Matsuno Y, Hirasawa Y, lizuka T, Studiawan H, et al. Studies on the constituents from the fruits of Phaleria macrocarpa. J Nat Med. 2008:62(2):207-10

26. Triastuti A, Choi JW. Protective effects of ethyl acetate fraction of Phaleria macrocarpa (Scheff) Boerl. on oxidative stress associated with alloxan-induced diabetic rats. J IIm Farm. 2008;5(1):9-17.

27. Sugiwati S, Setiasih S, Afifah E. Antihyperglycemic activity of the mahkota dewa [Phaleria macrocarpa (Scheff.) Boerl.] Leaf Extracts As An Alpha-Glucosidase Inhibitor. Makara Kesehat. 2009;13(2):74-8.

28. Rinayanti A, Radji M, Mun A, Suyatna FD. Screening Angiotensin Converting Enzyme (ACE) inhibitor activity of antihypertensive medicinal plants from indonesia. Int J Pharm Teach Pract. 2013;4(1):527-32

29. Anwar MA, Disi SS Al, Eid AH. Anti-hypertensive herbs and their mechanisms of action: Part II. Front Pharmacol. 2016;7.

30. June CC, Wen LH, Ani HA, Latif J, Gansau JA. Hypoglycemic effect of Gynura procumbens fraction on streptozotocin-induced diabetic rats Involved phosphorylation of GSK3 $\beta$ (ser-9) in liver. Sains Malaysia. 2012;41(8):969-75

31. Liu R, Chen $S$, Ren G, Shao F, Huang $H$. Phenolic compounds from roots of Imperata cylindrica var. major. Chinese Herb Med. 2013;5(3):240-3.

32. Guerrero L, Castillo J, Quiñones M, Garcia-Vallvé S, Arola L, Pujadas G, et al Inhibition of angiotensin-converting enzyme activity by flavonoids: structureactivity relationship studies. PLoS One. 2012;7(11):e49493.

33. Ellya Roa Delima YMS. The Effect of cogongrass (Imperata cylindrica (L.) P. Beauv) in lowering blood pressure. https://repository.maranatha. edu/12848/10/1110220_Journal.pdf.

34. Inamdar EK, Yeole RD, Ghogare AB, Souza NJ De. Determination of biologically active constituents in Centella asiatica. J Chromatogr A. 1996;742:127-30.

35. Maneesai $P$, Bunbupha $S$, Kukongviriyapan U, Prachaney $P$, Tangsucharit $P$ Asiatic acid attenuates renin-angiotensin system activation and improves vascular function in high-carbohydrate, high-fat diet fed rats. BMC Complement Altern Med. 2016;1-11.

36. Nor E, Abd A, Ismail A, Omar MN, Rahmat UN, Ismail A, et al. GC-MS Analysis of Phytochemical Compounds in Syzygium polyanthum leaves extracted using ultrasound-assisted method. Pharmacogn Journal. 2018;10(1):110-9.

37. Muhammad IR, Ester $\mathrm{MH}$. Pharmacological activity, active compounds, and mechanism of action bay leaf (Syzygium polyanthum): Review. In: Prosiding Seminar Nasional \& Workshop "Perkembangan Terkini Sains Farmasi \& Klinik. 2015.

38. Estevam C, Damiani N, Venturini L, Valentim D. Vasorelaxant effects of eugeno on rat thoracic aorta. Vascul Pharmacol. 2003:40:59-66.

39. Ismail A, Mohamed M, Sulaiman SA, Ahmad WANW. Autonomic nervous system mediates the hypotensive effects of aqueous and residual methanolic extracts of Syzygium polyanthum (Wight) Walp. var Polyanthum leaves in anaesthetized rats. Evidence-Based Complement Altern Med. 2013;2013.

40. Muthia R, Suganda AG, Sukandar EY. Angiotensin-I converting enzyme (ACE) inhibitory activity of several indonesian medicinal plants. Res J Pharm Biol Chem Sci. 2017;8(1S):192-9. 


\section{GRAPHICAL ABSTRACT}

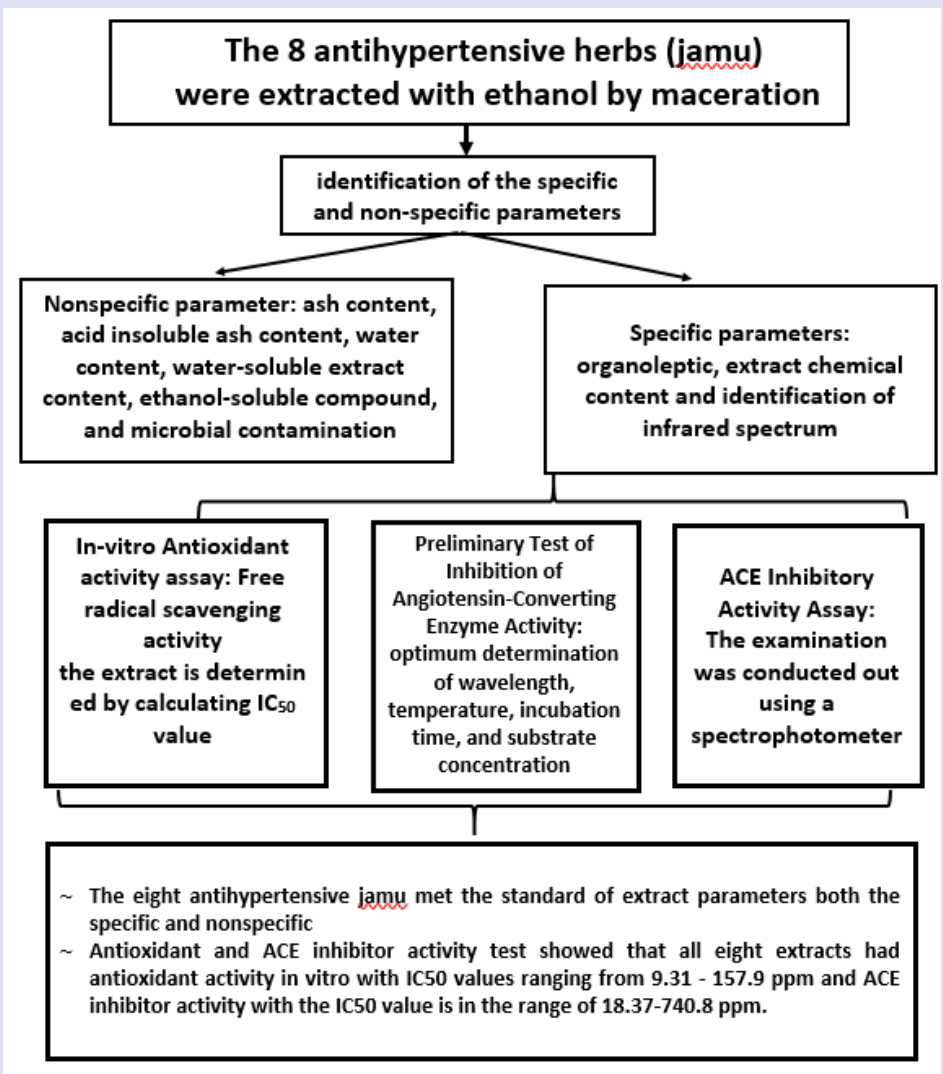

\section{ABOUT AUTHORS}

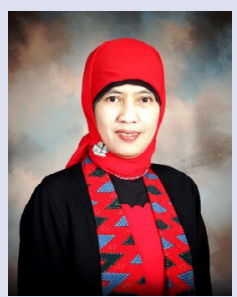

Aprilita Rina Yanti Eff was born in Tanjung Karang, Indonesia, in 1968. He received a bachelor's degree in Pharmacy from Universitas Padjadjaran, Bandung, Indonesia, in 1992, and the Magister Biomedic and Ph.D. degrees in Medical and Pharmacy Faculty, from the Universitas Indonesia, Jakarta, in 2001 and 2010, respectively. In 2001, she joined the Department of Pharmacy, UTA 45 Jakarta University as a Lecturer. Since 2015, he has been with the Department of Pharmacy, Universitas Esa Unggul, where he has been an Assistant Professor, became an Associate Professor in 2010. Her current research interests include herbal medicine, Pharmacology, and clinical Pharmacy.

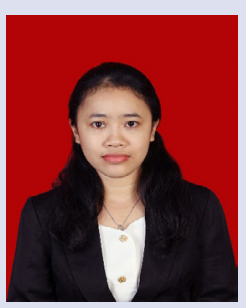

Putu Gita Maya W. Mahayasih, finished her magister program in pharmacy, at faculty of Pharmacy, Universitas Indonesia. She focused her research on natural product field. Currently, she is a lecture at Pharmacy department, faculty of health and sciences, Universitas Esa Unggul.

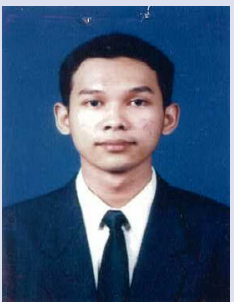

Moehammad Unggul Januarko, finished his magister program in Management, at faculty of Economic and Bussiness, Universitas Gajah Mada. She focused her research on management field. Currently, she is a lecture at Management department, faculty Economic and Bussiness, Universitas Esa Unggul. 


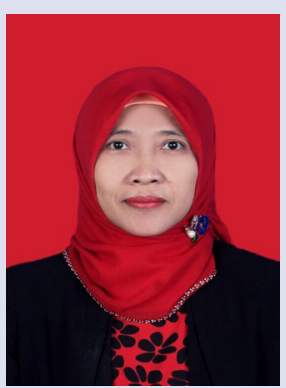

Sri Teguh Rahayu, was born in Jakarta, Indonesia, in 1972. Her received a bachelor's degree in Pharmacy from Universitas 17 Agustus 1945, Jakarta, Indonesia, in 2006, she finished the Magister Pharmacy and Ph.D. degrees Pharmacy Faculty, from the Universitas Indonesia, Jakarta, in 2011 and 2018, respectively. In 2006, she joined the Department of Pharmacy, Universitas 17 Agustus 1945, Jakarta University as a Lecturer. Since 2015, he has been with the Department of Pharmacy, Universitas Esa Unggul, where he has been an Assistant Professor in 2018. Her current research interests include pharmaceutical analysis, bioanalysis and herbal medicine.

Cite this article: Yanti Eff AR, Rahayu ST, Mahayasih PG, Januarko MU. Standardization of Indonesian Traditional Antihypertensive Medicines (Jamu) through the ACE Inhibitor Mechanism. Pharmacog J. 2020;12(3):422-9. 